\title{
Formulasi dan Evaluasi Larutan Pencuci Mulut dengan Bahan Antimikroba Senyawa 1,5-Bis (3'-Etoksi-4'-Hidroksifenil)-1,4- Pentadien-3-On
}

\author{
(Formulation and Evaluation of Mouthwash with 1,5-Bis(3'- \\ Etoksi-4'-Hidroksifenil)-1,4-Pentadien-3-On As Antimicrobial \\ Ingredient)
}

ESTI MUMPUNI*, AGUS PURWANGGANA, ESTI MULATSARI, RYAN PRATAMA

Fakultas Farmasi, Universitas Pancasila

Diterima 12 November 2018, Disetujui 4 April 2019

\begin{abstract}
Abstrak: Senyawa 1,5-bis(3'-etoksi-4'-hidroksifenil)-1,4-pentadien-3-on (EHP) merupakan analog kurkumin yang memiliki aktivitas antimikroba. Pada penelitian ini, dilakukan formulasi dan evaluasi larutan pencuci mulut dengan EHP sebagai bahan aktif antimikroba. Penelitian ini bertujuan untuk membuat formula dan menguji kestabilan formula obat kumur dengan bahan aktif EHP. Formulasi larutan pencuci mulut dibuat dengan variasi konsentrasi senyawa EHP 3, 6, 12, 16 dan 18 bpj. Evaluasi larutan pencuci mulut meliputi uji organoleptik, $\mathrm{pH}$, kejernihan, bobot jenis dan aktivitas antimikroba terhadap Staphylococcus aureus, Steptococcus mutans, dan Candida albicans. Uji antimikroba dilakukan dengan metode diffusi agar. Hasil evaluasi sediaan obat yang didapat dari pengujian organoleptik antara lain obat kumur berupa cairan dengan warna biru jernih, aroma mint dan rasa segar; memiliki rentang pH 6,15 - 6,74; dan bobot jenis 1,0419-1,0561 g/ $\mathrm{cm}^{3}$. Evaluasi larutan pencuci mulut menunjukkan bahwa larutan pencuci mulut stabil dalam penyimpanan selama 1 bulan pada suhu $40^{\circ} \mathrm{C}$. Uji antimikroba menunjukkan diameter daya hambat terhadap bakteri Staphylococcus aureus (ATCC 6538); Streptococcus mutans (ATCC 31987) dan Candida albicans (ATCC 10231) berkisar antara 6,2$8,4 \mathrm{~mm}$ pada konsentrasi senyawa EHP $18 \mathrm{bpj}$. Hasil ini menunjukkan bahwa senyawa EHP sangat potensial digunakan sebagai bahan antimikroba dalam formula larutan pencuci mulut.
\end{abstract}

Kata kunci: EHP, antimikroba, obat kumur.

\begin{abstract}
EHP) compound is an analogous compound of curcumin which has antimicrobial activity. In this study, the formulation and evaluation of mouthwash was carried out with EHP as an antimicrobial ingredient. The formulation of mouthwash was made with various concentrations of EHP 3, 6, 12, 16 and 18 ppm. Evaluation of mouthwash included organoleptic test, $\mathrm{pH}$, clarity, density and antimicrobial activity against Staphylococcus aureus, Steptococcus mutans, and Candida albicans. Antimicrobial test was done by agar diffusion method. The results of organoleptic test obtained mouthwash was clear blue liquid, the aroma of mint, and fresh cold taste; $\mathrm{pH}$ range of $6.15-6.74$; density of $1.0419-1.0561 \mathrm{~g} / \mathrm{cm} 3$. The evaluation of mouthwash showed that the mouthwash was stable in storage for 1 month at $40{ }^{\circ} \mathrm{C}$. Antimicrobial tests showed the diameter of inhibitory zone against Staphylococcus aureus (ATCC 6538); Streptococcus mutans (ATCC 31987) and Candida albicans (ATCC 10231) ranged from 6.2 to $8.4 \mathrm{~mm}$ at the concentration of EHP $18 \mathrm{ppm}$. The results showed that EHP compound was potential as antimicrobial ingredient in moutwash formula.
\end{abstract}

Keywords: EHP, antimicrobial,mouthwash. 


\section{PENDAHULUAN}

SENYAWA 1,5-bis(3'-etoksi-4'-hidroksifenil)-1,4pentadien-3-on (EHP) merupakan senyawa analog kurkumin yang telah berhasil disintesis Mumpuni et al $2010^{(1)}$. Struktur kimia senyawa EHP ditunjukkan pada Gambar 1.<smiles>CCOc1cc(/C=C/C(=O)/C=C/c2ccc(O)c(OCC)c2)ccc1O</smiles>

Gambar 1. Struktur kimia senyawa EHP.

Senyawa EHP memiliki aktivitas antioksidan dan antiinflamasi yang lebih baik dibandingkan kurkumin maupun senyawa modifikasi kurkumin lainnya. Toksisitas senyawa ini digolongkan toksik ringan dengan nilai $\mathrm{LD}_{50} 6,87 \mathrm{~g} / \mathrm{kg}$ BB. EHP mempunyai aktivitas antiinflamasi dengan dosis $137,35 \mathrm{mg} / \mathrm{kg}$ BB; 274,70 mg/kg BB; dan 549,40 mg/kg BB sama dengan aspirin $90 \mathrm{mg} / 200 \mathrm{~g} \mathrm{BB}^{(2)}$.

Senyawa EHP juga berpotensi sebagai antibakteri. Uji in silico menunjukkan EHP memiliki aktivitas antibakteri yang sangat baik. Hal ini ditunjukkan dengan nilai ChemPLP EHP (-91.2811) yang jauh lebih rendah pada reseptor atau enzim pengangkut D-Alanil-D-Alanin (DACA) dengan kode pdb 3MZD dibandingkan dengan asil kloksasilin yang merupakan ligan native nya $(-81,9278)$. Nilai tersebut juga lebih rendah dari nilai ChemPLP amoxicillin dan sefadroksil $(-87,5589$ dan $-85,4997)$. Uji secara in vitro menunjukkan bahwa senyawa EHP memiliki potensi sebagai antibakteri yang lebih baik dibandingkan dengan antibiotik amoxicillin dan sefadroksil dengan nilai konsentrasi hambat minimum (KHM) 0,15 bpj dan diameter daerah hambat (DDH) $11 \mathrm{~mm}$ pada bakteri gram positif maupun gram negatif $f^{(3)}$.

Bakteri, baik aerob maupun anaerob, merupakan salah satu pemicu terjadinya suatu infeksi dengan cara menginvasi dan berkembang biak dalam jaringan tubuh atau di dalam rongga mulut. Mulut merupakan tempat ratusan bakteri yang dapat memproduksi berbagai subtansi yang memberi bau busuk sebagai hasil degradasi protein ${ }^{(4)}$. Infeksi pada ronga mulut sering kali melibatkan bakteri aerob dan anaerob seperti Staphylococcus aureus, Streptococcus mutans dan Candida albicans. Mikroba tersebut merupakan bakteri flora normal pada selaput mukosa saluran pencernaan, tetapi dalam jumlahya yang meningkat akan menjadi patogen. Bakteri aerob yang dapat menyebabkan infeksi gigi dan mulut adalah
Staphylococcus aureus dan Streptococcus mutans dengan cara menginvasi dan berkembang biak dalam jaringan tubuh atau rongga mulut ${ }^{(5,6)}$. Infeksi rongga mulut juga dapat disebabkan oleh infeksi jamur Candida albicans disebut sebagai kandidiasis ${ }^{(7)}$. Infeksi Candida albicans sangat jarang terjadi, dan biasanya terjadi pada kondisi dimana keseimbangan flora normal terganggu, atau terdapat gangguan imunitas. Kandidiasis mulut muncul sebagai patch berwarna putih pada selaput lendir mulut, lidah dan bagian lain dalam mulut.

Larutan pencuci mulut merupakan suatu larutan air yang digunakan sebagai pembersih untuk meningkatkan kesehatan rongga mulut, estetika dan kesegaran nafas ${ }^{(8)}$. Larutan pencuci mulut dapat digunakan untuk membunuh bakteri, menghilangkan bau tak sedap dan mencegah karies ${ }^{(9)}$. Ada berbagai macam larutan pencuci mulut yang telah beredar di pasaran saat ini. Bahan aktif yang digunakan antara lain menthol, thymol, hexetidine, dan metil salisilat. Berbagai penelitian tentang formulasi dan evaluasi larutan pencuci mulut dengan bahan aktif kimia maupun alami juga telah banyak dilakukan, antara lain : larutan pencuci mulut dengan bahan aktif ekstrak poliherbal ${ }^{(10,11)}$, rosmarinus officinalis ${ }^{(12)}$, euphorbia hirta ${ }^{(13)}$, libidibia ferrea ${ }^{(14)}$. Pada penelitian ini dilakukan formulasi dan evaluasi larutan pencuci mulut dengan menggunakan senyawa EHP sebagai bahan antimikroba. Formulasi ini diharapkan dapat memberi alternative produk larutan pencuci mulut baru yang memiliki antibakteri yang baik dan lebih ekonomis.

\section{BAHAN DAN METODE}

BAHAN. Bahan yang akan digunakan dalam penelitian adalah senyawa EHP hasil sintesis yang mengacu prosedur sintesis dan karakterisasi oleh Mumpuni et al, 2010, media nutrient agar (NA), kaldu pepton, saburo dextrose agar, akuades, Na lauryl sulfat, sorbitol, propilen glikol, mentol, brilliant blue, bakteri uji yang digunakan Streptococcus mutans (ATCC31987), Staphylococcus aureus (ATCC 6538), Candida albicans (10231).

Alat. Alat-alat yang digunakan dalam penelitian ini antara lain timbangan analitik, timbangan mikro (Mettler MT5), oven microwave (Cevilla, CMG 003), stir plate \& stirer, piknometer (Iwaki), alat-alat gelas (Pyrex), alat-alat volumetrik, $\mathrm{pH}$ meter, kertas saring, spatula, kertas perkamen, pipa kapiler, Laminar Air Flow cabinet, lampu spiritus, oven, jarum ose, kapas, dan rak tabung.

METODE. Formulasi Larutan Pencuci Mulut. 
Formulasi larutan pencuci mulut dibuat dengan variasi konsentrasi EHP 3 bpj, 6 bpj, 12 bpj, 16 bpj dan 18 bpj menggunakan formula standard dengan penambahan rasa dan coloring agent. Formula larutan pencuci mulut disajikan pada Tabel 1. dengan cara melarutkan 1,0 g hidrazin sulfat dalam air secukupnya hingga 100,0 mL, dibiarkan selama 4-6 jam. Pada 25,0 mL larutan ditambahkan larutan 2,5 $\mathrm{mL} \mathrm{g}$ heksamin dalam 25,0 mL air, dicampurkan dan dibiarkan selama 24 jam. Sebanyak 15,0 mL suspensi

Tabel 1. Formulasi larutan pencuci mulut.

\begin{tabular}{lccccc}
\hline \multirow{2}{*}{ Bahan } & \multicolumn{5}{c}{ Formulasi (\%) } \\
\cline { 2 - 6 } & Formula I & Formula II & Formula III & Formula IV & Formula IV \\
\hline EHP & $1 \mathrm{bpj}$ & $2 \mathrm{bpj}$ & $4 \mathrm{bpj}$ & $8 \mathrm{bpj}$ & $18 \mathrm{bpj}$ \\
Sorbitol & 10 & 10 & 10 & 10 & 10 \\
Propilen glikol & 15 & 15 & 15 & 15 & 15 \\
Natrium benzoat & 0,1 & 0,1 & 0,1 & 0,1 & 0,1 \\
Essence orange & 0,1 & 0,1 & 0,1 & 0,1 & 0,1 \\
Sunset yellow & 0,005 & 0,005 & 0,005 & 0,005 & 0,005 \\
Air suling ad & 100 & 100 & 100 & 100 & 100 \\
\hline
\end{tabular}

Pembuatan Larutan Pencuci Mulut. Sejumlah $50 \mathrm{mg}$ EHP dilarutkan dengan air suling dalam labu tentukur $100 \mathrm{~mL}$, sehingga diperoleh larutan induk EHP dengan konsentrasi 500 bpj. Larutan induk dipipet sesuai kebutuhan masing-masing formula dimasukkan ke dalam labu takar $100 \mathrm{~mL}$. Natrium benzoat dilarutkan dalam sebagian air suling,kemudian ditambahkan propilen glikol dan sorbitol, aduk hingga homogen (campuran I). Tambahkan sunset yellow dan essence orange ke dalam campuran I, diaduk hingga homogen (campuran II). Masing-masing labu tentukur yang berisi EHP diencerkan dengan campuran II. Tambahkan air suling hingga volume $100 \mathrm{~mL}$.

Evaluasi Fisika dan Kimia. Evaluasi fisika dan kimia digunakan untuk uji stabilitas larutan pencuci mulut. Uji stabilitas dilakukan dengan menggunakan climatic chamber pada suhu $\pm 40{ }^{\circ} \mathrm{C}$ selama 1 bulan. Larutan pencuci mulut dibiarkan berkesetimbangan selama 3 hari pada suhu kamar, dilakukan evaluasi fisika dan kimia meliputi uji organoleptik, kejernihan, bobot jenis, dan $\mathrm{pH}$. Uji aktivitas antimikroba dengan mengukur diameter daerah hambat (DDH).

Pemeriksaan Organoleptik. Pemeriksaan organoleptik meliputi warna, bau dan rasa. Pengamatan warna dilakukan secara visual terhadap larutan pencuci mulut yang dikemas dalam botol bening. Bau dari larutan pencuci mulut yang telah disimpan dalam wadah yang sesuai dengan cara membuka tutup botol dan mencium aromanya. Rasa dari larutan pencuci mulut diuji dengan cara mencicipi (berkumur) sesuai takaran.

Uji Kejernihan. Uji kejernihan diawali dengan pembuatan baku opelesen. Baku opalesen dibuat diencerkan dengan air $1000 \mathrm{~mL}$. Suspensi harus digunakan dalam waktu 24 jam setelah pembuatan. Suspensi padanan dibuat dengan formulasi pada Tabel $2^{(15)}$.

Tabel 2. Komposisi suspensi padanan baku opelesan

\begin{tabular}{lcccc}
\hline \multirow{2}{*}{ Bahan } & \multicolumn{4}{c}{ Suspensi padanan } \\
\cline { 2 - 5 } & I & II & III & IV \\
\hline $\begin{array}{l}\text { Baku } \\
\text { opalesen (mL) }\end{array}$ & 5,0 & 10,0 & 30,0 & 50,0 \\
Air (mL) & 95,0 & 90,0 & 70,0 & 50,0 \\
\hline
\end{tabular}

Penentuan kejernihan obat kumur dilakukan dengan membandingkan suspensi padanan baku dengan larutan uji (larutan pencuci mulut) yang dimasukkan dalam tabung reaksi alas datar dengan diameter 15$25 \mathrm{~mm}$, tidak berwarna, transparan, dan terbuat dari kaca netral dengan latar belakang hitam kemudian diamati di bawah cahaya yang terdifusi, tegak lurus ke arah bawah tabung. Difusi cahaya harus sedemikian rupa sehingga suspensi padanan I dapat langsung dibandingkan dengan suspensi padanan II. Suatu cairan dinyatakan jernih jika kejernihannya sama dengan air atau pelarut yang digunakan bila diamati di bawah kondisi di atas atau jika okupalensinya tidak lebih nyata dari suspensi padanan I.

Uji Bobot Jenis. Penentuan bobot jenis menggunakan piknometer dan didasarkan pada perbandingan bobot cairan di udara pada suhu 25 ${ }^{\circ} \mathrm{C}$ terhadap bobot air dengan volume dan suhu yang 
sama. Larutan pencuci mulut yang suhunya telah diatur $\pm 25^{\circ} \mathrm{C}$ dimasukkan ke dalam piknometer. Suhu piknometer yang telah diisi kemudian diatur hingga 25 ${ }^{\circ} \mathrm{C}$. Kelebihan zat uji dibuang kemudian ditimbang.

Bobot jenis dihitung berdasarkan rumus:

$$
\text { Bobot jenis }=\frac{\text { bobot piknometer }+ \text { zat }-(\text { bobot piknometer kosong })}{\text { bobot piknometer }+ \text { air }-(\text { bobot piknometer kosong) }}
$$

Uji pH. Penentuan pH larutan pencuci mulut menggunakan $\mathrm{pH}$ meter yang telah dikalibrasi. Larutan pencuci mulut yang akan diukur disiapkan. Elektrode pH meter dicelupkan sampai ujung elektroda tercelup ke dalam sediaan. $\mathrm{pH}$ yang didapat dicatat, pembacaan dilakukan 3 kali.

Uji Potensi Antibakteri Larutan Pencuci Mulut. Uji potensi antibakteri dilakukan pada setiap formula larutan pencuci mulut senyawa EHP, kontrol negatif larutan pencuci mulut tanpa senyawa EHP, serta kontrol positif berupa sediaan antiseptik obat kumur yang beredar di pasaran yaitu Listerin. Uji potensi antibakteri larutan pencuci mulut secara in vitro dengan mengukur Diameter Daerah Hambat (DDH) dari larutan pencuci mulut terhadap bakteri Staphylococcus aureus, Streptococcus mutans dan Candida albicans. Metode yang dilakukan adalah difusi agar dengan menggunakan kertas cakram ${ }^{(16)}$.

Pembuatan Media Peremajaan untuk Mikroba Uji. Pembuatan Media Agar Miring. Media yang digunakan adalah Nutrient Agar (NA). Bahan dicampur sambil dipanaskan hingga homogen. Media yang sudah homogen dimasukkan ke dalam masingmasing tabung reaksi sebanyak $5 \mathrm{~mL}$ lalu mulut tabung ditutup dengan kapas. Media disterilkan dalam autoklaf pada suhu $121{ }^{\circ} \mathrm{C}$ selama 15 menit. Media yang telah disterilkan dibiarkan pada posisi miring sampai memadat pada suhu kamar.

Pembuatan Media Cair. Untuk media cair digunakan kaldu pepton. Bahan dicampur sambil dipanaskan hingga homogen. Media yang telah homogen dimasukkan ke dalam masing-masing tabung reaksi sebanyak $5 \mathrm{~mL}$ dan mulut tabung ditutup dengan kapas. Media disterilkan dalam autoklaf pada suhu $121{ }^{\circ} \mathrm{C}$ selama 15 menit. Media cair digunakan untuk penyiapan suspensi mikroba uji.

Peremajaan Mikroba Uji. Peremajaan dilakukan dengan menginokulasikan 1 ose mikroba uji ke dalam media miring Nutrient Agar (NA) untuk semua mikroba uji, kemudian diinkubasi pada suhu $37{ }^{\circ} \mathrm{C}$ selama 18-24 jam.

Pembuatan Suspensi Mikroba Uji. Biakan mikroba pada agar miring yang berumur 24 jam, diambil 1 ose mikroba menggunakan jarum ose atau sengkelit dan dimasukkan ke dalam $5 \mathrm{~mL}$ media kaldu pepton, kemudian diinkubasi kembali pada suhu $37{ }^{\circ} \mathrm{C}$ selama $18-24$ jam. Suspensi mikroba diukur transmitannya menggunakan spektrofotometer UVcahaya tampak dengan panjang gelombang $580 \mathrm{~nm}$, hingga mempunyai harga transmitan $25 \% \mathrm{~T}$.

Pengujian Daya Hambat Senyawa EHP dalam Larutan Pencuci Mulut terhadap Mikroba Uji (Metode Difusi Agar). Suspensi mikroba uji 25\% T sebanyak dimasukkan ke dalam masing-masing cawan petri steril, dan ditambahkan 15-20 mL media Nutrient Agar (NA). Campuran suspensi mikroba dengan media Nutrient Agar (NA) dihomogenkan dengan menggoyangkan cawan petri secara perlahan, dan dibiarkan memadat pada suhu kamar selama 1530 menit. Campuran yang telah memadat dimasukkan cakram yang telah dijenuhkan dengan larutan larutan pencuci mulut dengan berbagai konsentrasi ke dalam agar dan diinkubasi pada suhu $35-37{ }^{\circ} \mathrm{C}$ selama 18 24 jam. Zona bening yang terbentuk diukur dengan satuan millimeter ( $\mathrm{mm}$ ). Zona bening disekitar cakram menunjukkan adanya daerah hambatan mikroba.

\section{HASIL DAN PEMBAHASAN}

Evaluasi Larutan Pencuci Mulut Berbahan Aktif Senyawa EHP. Uji stabilitas dilakukan dengan menggunakan climatic chamber pada suhu $\pm 40{ }^{\circ} \mathrm{C}$ selama 1 bulan. Pengamataan dan evaluasi sediaan meliputi pemeriksaan organoleptik obat kumur, kejernihan, bobot jenis, dan $\mathrm{pH}$ sediaan. Formula larutan pencuci mulut dibuat dalam lima macam formula.

Pemeriksaan Organoleptik Larutan Pencuci Mulut. Pemeriksaan organoleptik yang dilakukan meliputi warna, bau dan rasa dari sediaan. Kelima komponen ini dibandingkan selama waktu penyimpanan. Hasil pemeriksaan organoleptik larutan pencuci mulut dapat dilihat dari Tabel 3 dan kenampakan fisik larutan pencuci mulut ditunjukkan Gambar 2. Uji stabilitas fisik dilakukan meliputi stabilitas warna, aroma, dan rasa dari obat kumur untuk mengetahui terjadi perubahan atau tidak terjadi perubahan secara fisik. Hasil uji stabilitas fisik menunjukkan bahwa pada minggu ke empat formula I; II; III; IV; dan V tidak mengalami perubahan baik warna, bau maupun aroma. Hal ini menandakan bahwa larutan pencuci mulut dengan formulasi tersebut stabil. Hasil pengamatan secara visual terlihat bahwa larutan pencuci mulut berwarna biru. Hal tersebut dikarenakan penambahan brilliant blue pada masingmasing formula obat kumur untuk meningkatkan ketertarikan pengguna. Sedangkan bau khas dari sediaan dihasilkan dari mentol yang ditambahkan 
pada sediaan untuk meningkatkan kesukaan dan memberikan rasa segar pada saat digunakan. penggunaan pelarut campur berupa propilen glikol, sorbitol, etanol serta sodium lauril sulfat sebagai

Tabel 3. Hasil pemeriksaan organoleptik larutan pencuci mulut.

\begin{tabular}{|c|c|c|c|c|c|c|c|c|c|c|c|c|c|c|c|}
\hline \multirow[b]{2}{*}{ Minggu ke } & \multicolumn{15}{|c|}{ Hasil Uji Organoleptik } \\
\hline & \multicolumn{3}{|c|}{ Formula I } & \multicolumn{3}{|c|}{ Formula II } & \multicolumn{3}{|c|}{ Formula II } & \multicolumn{3}{|c|}{ Formula IV } & \multicolumn{3}{|c|}{ Formula V } \\
\hline 1 & $\mathrm{~B}$ & $\mathrm{~K}$ & $\mathrm{~S}$ & B & $\mathrm{K}$ & $\mathrm{S}$ & B & $\mathrm{K}$ & $\mathrm{S}$ & $\mathrm{B}$ & $\mathrm{K}$ & $\mathrm{S}$ & $\mathrm{B}$ & $\mathrm{K}$ & $\mathrm{S}$ \\
\hline 3 & $\mathrm{~B}$ & $\mathrm{~K}$ & $\mathrm{~S}$ & $\mathrm{~B}$ & $\mathrm{~K}$ & $\mathrm{~S}$ & B & $\mathrm{K}$ & $\mathrm{S}$ & $\mathrm{B}$ & $\mathrm{K}$ & $\mathrm{S}$ & $\mathrm{B}$ & $\mathrm{K}$ & $\mathrm{S}$ \\
\hline 4 & $\mathrm{~B}$ & $\mathrm{~K}$ & $\mathrm{~S}$ & B & $\mathrm{K}$ & $\mathrm{S}$ & B & $\mathrm{K}$ & $\mathrm{S}$ & $\mathrm{B}$ & $\mathrm{K}$ & $\mathrm{S}$ & $\mathrm{B}$ & $\mathrm{K}$ & $\mathrm{S}$ \\
\hline
\end{tabular}

Keterangan :

$\begin{array}{ll}\text { W : Warna } & \text { B : Biru } \\ \text { A : Aroma } & \text { K : Khas mentol } \\ \text { R : Rasa } & \text { S : Segar }\end{array}$

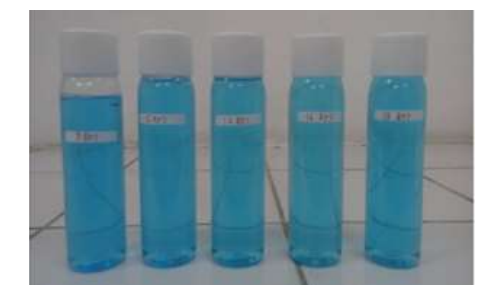

Gambar 2. Foto fisik larutan pencuci mulut.

Uji Kejernihan Larutan Pencuci Mulut. Kejernihan obat kumur ditentukan dengan cara memendarkan suatu berkas cahaya terfokus kedalam larutan obat kumur yang telah dibuat. Suatu sediaan dikatakan jernih jika jernihnya sama dengan air atau jika baku okupalensinya tidak lebih nyata dari suspensi padanan $^{(15)}$. Hasil pengamatan uji kejernihan larutan pencuci mulut disajikan pada Tabel 4. surfaktan yang digunakan untuk meningkatkan kelarutan EHP, sehingga didapatkan hasil pengujian kejernihan yang stabil. Natrium lauril sulfat merupakan surfaktan anionik yang bekerja dengan mekanisme solubilisasi miselar, yaitu dengan membentuk misel. Bila surfktan cenderung ditambahkan ke dalam air pada konsentrasi rendah, surfaktan tersebut cenderung mengarah pada antar permukaan udara-cairan. Pada konsentrasi lebih tinggi, molekul surfaktan akan mulai membentuk agregat yang terarah (misel). Kemudian dengan adanya kosolvensi seperti sorbitol, etanol, propilen glikol dan ditambah air dapat meningkatkan kelarutan, dimana zat yang kurang polar dalam hal ini senyawa EHP dapat diinduksi polaritasnya menjadi lebih polar sehingga dapat larut dalam kosolven tersebut.

Uji Bobot Jenis Larutan Pencuci Mulut. Penentuan bobot jenis menggunakan piknometer

Tabel 4. Hasil pengujian uji kejernihan larutan pencuci mulut .

\begin{tabular}{ccccccccccc}
\hline \multirow{2}{*}{ Minggu ke } & \multicolumn{2}{l}{ Formula I } & \multicolumn{2}{c}{ Formula II } & \multicolumn{2}{c}{ Formula III } & \multicolumn{2}{c}{ Formula IV } & \multicolumn{2}{c}{ Formula V } \\
\cline { 2 - 11 } & I & II & I & II & I & II & I & II & I & II \\
\hline 0 & 1 & 1 & 1 & 1 & 1 & 1 & 1 & 1 & 1 & 1 \\
1 & 1 & 1 & 1 & 1 & 1 & 1 & 1 & 1 & 1 & 1 \\
2 & 1 & 1 & 1 & 1 & 1 & 1 & 1 & 1 & 1 & 1 \\
4 & 1 & 1 & 1 & 1 & 1 & 1 & 1 & 1 & 1 & 1 \\
\hline
\end{tabular}

Berdasarkan hasil data pada Tabel 4 menunjukkan bahwa tidak terdapat kekeruhan pada sediaan selama waktu penyimpanan, karena bahan-bahan dalam sediaan dapat larut sempurna. Hal ini disebabkaan oleh dan didasarkan pada perbandingan bobot cairan di udara pada suhu $25^{\circ} \mathrm{C}$ terhadap bobot air dengan volume dan suhu yang sama. Berikut hasil uji bobot jenis larutan pencuci mulut dapat dilihat pada 
Gambar 3. Bobot jenis adalah rasio bobot suatu zat terhadap bobot zat baku yang volumenya sama pada suhu yang sama dan dinyatakan dalam desimal. Bobot jenis digunakan sebagai metode analisis yang untuk menentukan senyawa cair, uji identitas, dan kemurnian dari senyawa obat terutama cairan, serta dapat mengetahui tingkat kelarutan/daya larut suatu zat. Grafik pada Gambar 3 menunjukkan bahwa bobot jenis dari sediaan yang disimpan pada suhu $40{ }^{\circ} \mathrm{C}$ tidak mengalami perubahan yang signifikan selama penyimpanan. Selain itu karena kelima formula menggunakan air murni sebagai komponen utama pelarut, maka didapatkan nilai bobot jenis yang mendekati nilai bobot jenis air yaitu 1,00. Hasil analis statistik dengan metode ANOVA satu arah diperoleh nilai $\mathrm{p}=0,862>0,05$, artinya waktu simpan tidak berpengaruh signifikan terhadap perubahan bobot jenis larutan pencuci mulut.

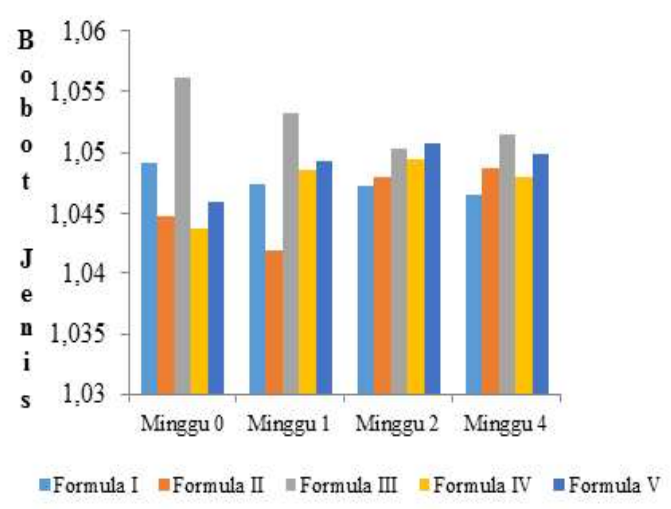

Gambar 3. Grafik bobot jenis pada suhu $\pm 40{ }^{\circ} \mathrm{C}$.

Analisis pH Larutan Pencuci Mulut. Hasil analisis $\mathrm{pH}$ larutan pencuci mulut ditunjukkan pada Gambar 4.

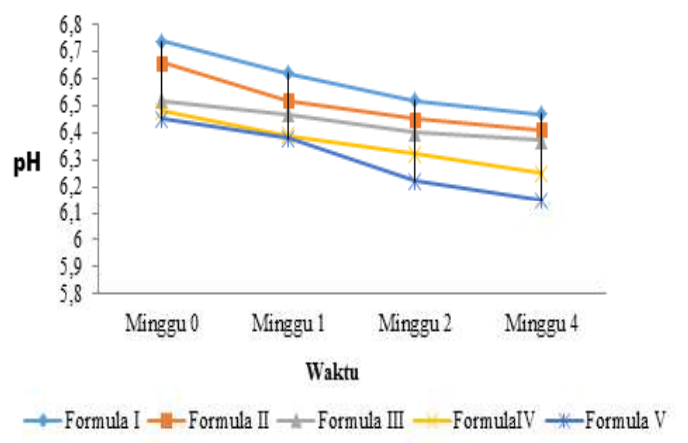

Gambar 4. Grafik pH pada suhu $\pm 40^{\circ} \mathrm{C}$
Hasil uji statistik pH selama 1 bulan menggunakan metode ANOVA satu arah untuk melihat pengaruh waktu simpan terhadap $\mathrm{pH}$. Hasil analisis statistik diperoleh nilai $\mathrm{p}=0,026<0,05$, hipotesis nol diterima, artinya waktu simpan berpengaruh terhadap perubahan $\mathrm{pH}$ larutan pencuci mulut. Akan tetapi perubahan tersebut tidak signifikan dan masih dalam rentang standar $\mathrm{pH}$ obat kumur yaitu $6-7 . \mathrm{pH}$ ini merupakan kondisi $\mathrm{pH}$ yang aman untuk mulut, tidak bersifat asam yang dapat menyebabkan korosif pada gigi dan tidak pula bersifat basa yang dapat mengganggu pengecapan.

Uji Aktivitas Antimikroba Larutan Pencuci Mulut. Pengujian efektivitas secara in vitro dilakukan dengan metode difusi cakram. Efektivitas antibakteri ditunjukkan Gambar 5 dengan terbentuknya zona bening di sekitar cakram yang sudah mengandung larutan obat kumur yang akan diuji. Zona bening pada lapisan agar yang terbentuk karena senyawa antibakteri berdifusi ke dalam lapisan tersebut dan menghambat pertumbuhan mikroorganisme, sedangkan lapisan agar yang ditumbuhi mikroorganisme akan tampak keruh.
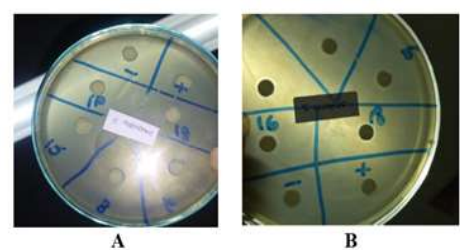

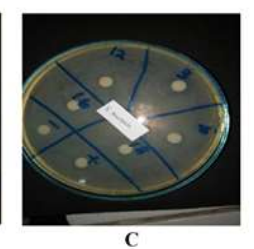

Gambar 5. Diameter daya hambat larutan pencuci mulut pada bakteri A) Candida albicans B) Staphylococcus aureus C) Strephtococcus mutans.

Hasil pengujian aktivitas antimikroba pada larutan pencuci mulut terhadap bakteri Streptococcus mutans, Staphylococcus aureus dan Candida albicans berdasarkan Diameter Daya Hambat (DDH) dapat dilihat pada Tabel 5. Uji efektivitas antimikroba dilakukan untuk melihat kemampuan larutan pencuci mulut dalam menghambat bakteri Streptococcus mutans, Staphylococcus aureus dan Candida albicans. Hasil Uji menunjukkan bahwa formula 5 memiliki nilai Diameter Daerah Hambat (DDH) yang lebih besar dibandingkan formula yang lainnya. Hal ini dikarenakan pada Formula V konsentrasi senyawa EHP yang digunakan lebih besar yaitu 18 bpj dibandingkan Formula I (3 bpj), Formula II (6 bpj), Formula III (12 bpj), dan Formula IV (16 bpj). Konsentrasi EHP yang digunakan mempengaruhi aktivitas terhadap Streptococcus mutans, Staphylococcus aureus dan Candida albicans dengan cara menghambat enzim transpeptidase yang menghubungkan D-alanil-Dalanil pada peptidoglikan dinding sel bakteri. Kontrol 
negatif yang digunakan adalah larutan pencuci mulut tanpa penambahan senyawa EHP. Pengujian kontrol negatif dilakukan untuk memastikan senyawa EHP memiliki aktifitas antimikroba. Kontrol positif yang digunakan adalah larutan pencuci mulut yang telah beredar di pasaran yaitu listerin yang mengandung senyawa seperti chlorhexidin, mentol, timol, etanol, asam benzoat, metil salisilat. Pengujian kontrol positif dilakukan untuk membandingkan keefektifitasan obat kumur senyawa EHP dengan obat kumur listerin yang beredar dipasaran dengan cara dilakukan uji aktivitas antimikroba secara in vitro. Hasil penelitian menunjukkan larutan pencuci mulut pada formula F5 memiliki aktivitas yang hampir sama dengan sediaan listerin yang beredar di pasaran.

Tabel 5. Hasil pengujian aktivitas antimikroba.

\begin{tabular}{cccc}
\hline \multirow{2}{*}{ Formula } & S. aureus & S. mutans & $\begin{array}{c}\text { C. } \\
\text { albicans }\end{array}$ \\
\cline { 2 - 4 } X & \multicolumn{3}{c}{ DDH (mm) } \\
\hline Y & 6 & 6 & 6 \\
F1 & 6,3 & 9 & 7,2 \\
F2 & 6,7 & 7,7 & 6,2 \\
F3 & 6,8 & 7,9 & 6,6 \\
F4 & 7,4 & 8,3 & 7 \\
F5 & 7,6 & 8,4 & 7,1 \\
\hline
\end{tabular}

Keterangan :

$\mathrm{X}=$ Formula pembanding (tanpa senyawa EHP)

F1 = Formula dengan Konsentrasi senyawa EHP 3 bpj

F2 = Formula dengan Konsentrasi senyawa EHP 6 bpj

F3 = Formula dengan Konsentrasi senyawa EHP 12 bpj

F4 = Formula dengan Konsentrasi senyawa EHP 16 bpj

F5 $=$ Formula dengan Konsentrasi senyawa EHP 18 bpj

$\mathrm{Y}=$ Sebagai kontrol positif (obat kumur dipasaran)

\section{SIMPULAN}

Dari penelitian ini dapat disimpulkan bahwa senyawa EHP dapat dIgunakan sebagai bahan antimikroba dalam larutan pencuci mulut. Formulasi larutan pencuci mulut dengan aktivitas terbaik ialah Formula $\mathrm{V}$ dengan konsentrasi EHP 18 bpj.

\section{UCAPAN TERIMA KASIH}

Ucapan terima kasih penulis sampaikan kepada Direktorat Jenderal Riset dan Pengembangan, Kementrian Riset dan Pendidikan Tinggi atas dana hibah penelitian yang telah diberikan melalui program
Penelitian Strategis Nasional Institusi.

\section{DAFTAR PUSTAKA}

1. Mumpuni E, Indriana P, Sulastri E, Rusnawan E. Synthesis and antioxidant test of 1.5-bis (3'ethoxy4'-hydroxyphenyl)-1,4-pentadiene-3-one (EHP). JIFI. 2010. 8:91-100.

2. Mumpuni, E., Rahayu, L., Nurrochmad, A. Toksisitas dan antiinflamasi senyawa 1,5-bis(3'-etoksi-4'hidroksifenil)-1,4-pentadien-3-on, JIFI . 2015. 13(1) : 45- 9

3. Purwanggana A, Mumpuni E, Mulatsari E. In vitro and in silico antibacterial activity of 1,5-bis(3'-ethoxy-4'hydroxyphenyl)-1,4-pentadiene-3-one. Int J. Pham Pham Sci. 2018. (10) $5: 71-6$.

4. Krespi Y P, Shrime M G, and Kacker A. The relationship between oral malodor and volatile sulfur compound-producing bacteria. American Journal Otolaryngology-Head and Neck Surgery. 2006. https:// doi.org/10.1016/j.otohns.2005.09.036

5. Komariah A. Staphylococcus aureus (in vitro) Antibacterial activity of nano chitosan on Staphylococcus aureus. Seminar Nasional XI Pendidikan Biologi FKIP UNS Biologi, Sains, Lingkungan, dan Pembelajarannya. Surakarta 1 November 2015. 12 (1): 371- 7.

6. Jawetz, Melnick, Adelberg. Mikrobiologi Kedokteran edisi 20. Alih Bahasa Nugroho E, Maulany RF. Jakarta: Penerbit Buku Kedokteran 1986. Hal 153-7, 627-8.

7. Power, J. M., dan Sakaguchi, R. I. Craig's Dental Materials 12th edition. 2006. Mosby Elsevier, St. Louis.p.

8. Akande, et al. Efficacy of different brands of mouthwash rinses on oral bacterial loud count in healthy adults. African Journal of Biomedical Research. 2004. 7 : 125 - 8

9. Phatak A.A, Patankar R.D, Galgatte U.C, et al. Antimicrobial activity of a poly-herbal extact against dental micro flora. Res J Pharm Bio Chem Sci. 2011. $2(2): 533-9$.

10. Banu J.N, and Gayathri V. Preparation of antibacterial herbal mouthwash against oral pathogens. Int J Curr Microbiol App Sci .2016. 5(11): $205-21$.

11. Paula I.M, Moraes F.C, Souza O.V, and Yamamoto C.H. Development of mouthwash with rosmarinus officinalis extract. Brazilian J Pharm Sci. 2014. 50 (4) : $851-8$.

12. Kono S.R, Yamlean P.V.Y, dan Sudewi S. Formulasi larutan pencuci mulut herba patikan kebo (Euphorbia hirta) dan uji antibakteri Prophyromonas gingivalis. Pharmacon Jurnal Ilmiah Farmasi-Unsrat. 2018. 7 (1) : 37-46.

13. Venancio G.N, et al. Herbal mouthwash based on libidibia ferrea: microbiological control, sensory characteristics, sedimentation, $\mathrm{pH}$ and density. Rev Odontol unesp 2015. 44 (2) : :118 - 24.

14. Departemen Kesehatan Republik Indonesia. Farmakope 
Indonesia. Edisi IV. Jakarta: Direktorat Jendral Pengawasan Obat dan Makanan; 1995. H.63-4, 529-0, 756-7, 998, 1039.

15. Hudzicki J. Kirby-Bauer disk diffusion susceptibility test protocol. 2009. American Society for Microbiology. 